5. Прокудин Ю.Н. Определитель высших растений Украины. К: Наукова думка. 1987. 545 с.

6. Протопопова В.В. Синантропная флора Украины и пути ее развития. К: Наукова думка. 1991. 200 с.

DOI https://doi.org/10.30525/978-9934-26-047-6-4

\title{
ІНТРОДУКОВАНІ ВИДИ РОСЛИН ПРИРОДНОЇ ФЛОРИ УКРАЇНИ ДЛЯ ДЕКОРАТИВНОГО САДІВНИЦТВА
}

\author{
Перебойчук О. П. \\ кандидат біологічних наук, \\ науковий співробітник відділу квітниково-декоративних рослин \\ Національний ботанічний сад імені М. М. Гришка \\ Національної академії наук Украӥни \\ Щербакова Т. О. \\ кандидат біологічних наук, \\ старший науковий співробітник відділу \\ квітниково-декоративних рослин \\ Начіональний ботанічний сад імені М. М. Гришка \\ Начіональної академії наук Украӥни \\ Машковська С. П. \\ кандидат біологічних наук, \\ стариий науковий співробітник \\ відділу квітниково-декоративних рослин \\ Начіональний ботанічний сад імені М. М. Гришка \\ Національної академії наук Украӥни \\ м. Київ, Украӥна
}

Розширення та оновлення асортименту квітниково-декоративних рослин $є$ основним завданням сучасного декоративного садівництва. Один із шляхів збагачення рослинних ресурсів - інтродукція та введення в культуру рослин природної флори різних регіонів. Перспективні у цьому відношенні рослини місцевих флор, які пристосовані до кліматичних умов регіону, характеризуються високою стійкістю i невибагливістю в культурі. Крім того, використання рослин цих видів в декоративному садівництві сприяє збереженню біорізноманіття, особливо рідкісних та ендемічних видів.

Мета роботи - аналіз біоекологічних особливостей інтродукованих у Національному ботанічному саду імені М.М. Гришка НАН України 
(НБС) квітниково-декоративних рослин природної флори України для розробки рекомендацій щодо використання їх в декоративному садівництві.

Інтродукційні дослідження, вивчення росту та розвитку рослин, фенологічні спостереження проводили за методиками $[1,4]$. Назви видів наведено згідно С.Л. Мосякіна і М.М. Федорончука для України та інтернет ресурсів [6-8]. Успішність інтродукції визначали на основі методичних розробок Р.А. Карпісонової [2] з власною модифікацією. Екоморфи встановлювали згідно системи екоморф рослин О.Л. Бельгарда, оптимізованої М.М. Матвєєвим [3].

До інтродукційного процесу було залучено 33 родини: Amarantaceae, Apiaceae, Apocynaceae, Aristolochiaceae, Asparagaceae, Aspleniaceae, Asteraceae, Boraginaceae, Brassicaceae, Campanulaceae, Caprifoliaceae, Caryophillaceae, Chenopodiaceae, Crassulaceae, Dryopteridaceae, Euphorbiaceae, Fabaceae, Gentianaceae, Geraniaceae, Lamiaceae, Linaceae, Papaveraceae, Plantaginaceae, Poaceae, Primulaceae, Ranunculaceae, Resedaceae, Rosaceae, Rutaceae, Scrophulariaceae, Valerianaceae, Verbenaceae, Violaceae.

За результатами багаторічних інтродукційних досліджень рослин природної флори України, проведеної оцінки їхніх декоративних характеристик та стійкості в культурі, виділено 142 види високоперспективних і перспективних рослин для використання у декоративному садівництві. Із них 16 видів мають охоронний статус $\mathrm{i}$ занесені до Червоної книги України. Перспективні інтродуценти представлені різними життєвими формами: однорічними трав'янистими рослинами (38 видів), багаторічними трав'янистими рослинами (101 вид), напівкущиками (3 види).

На основі аналізу біоекологічних особливостей інтродукованих представників ми розділили їх на групи щодо умов зволоження, освітлення та строків цвітіння (табл.). За відношенням рослин до вологості, провідне місце належить ксеромезофітам та мезофітам (73 види). Для більш посушливих умов рекомендовано 60 видів. Рослини цих біоморф походять зі степових, лугових та лісостепових фітоценозів, гірських ландшафтів Кримських гір. Найбільш вологолюбивими $є$ рослини 9 видів, які зустрічаються у лісових фітоценозах та на високогірних луках Карпат. Більшість досліджуваних видів придатні для вирощування на сонячних та напівсонячних місцях, 22 \% видів є тіневитривалими і тінелюбивими.

За строками цвітіння виділено п'ять феногруп: весняні (18,4\%), веснянолітні $(25,5 \%)$, літні $(46,1 \%)$, літньоосінні $(7,8 \%)$, осінні $(0,7 \%)$. Asplenium scolopendrium, Dryopteris filix-mas - виключно декоративнолистяні. 
Таблиця

Біоекологічні особливості інтродукованих видів природної флори України, які слід враховувати при використанні в декоративному садівництві

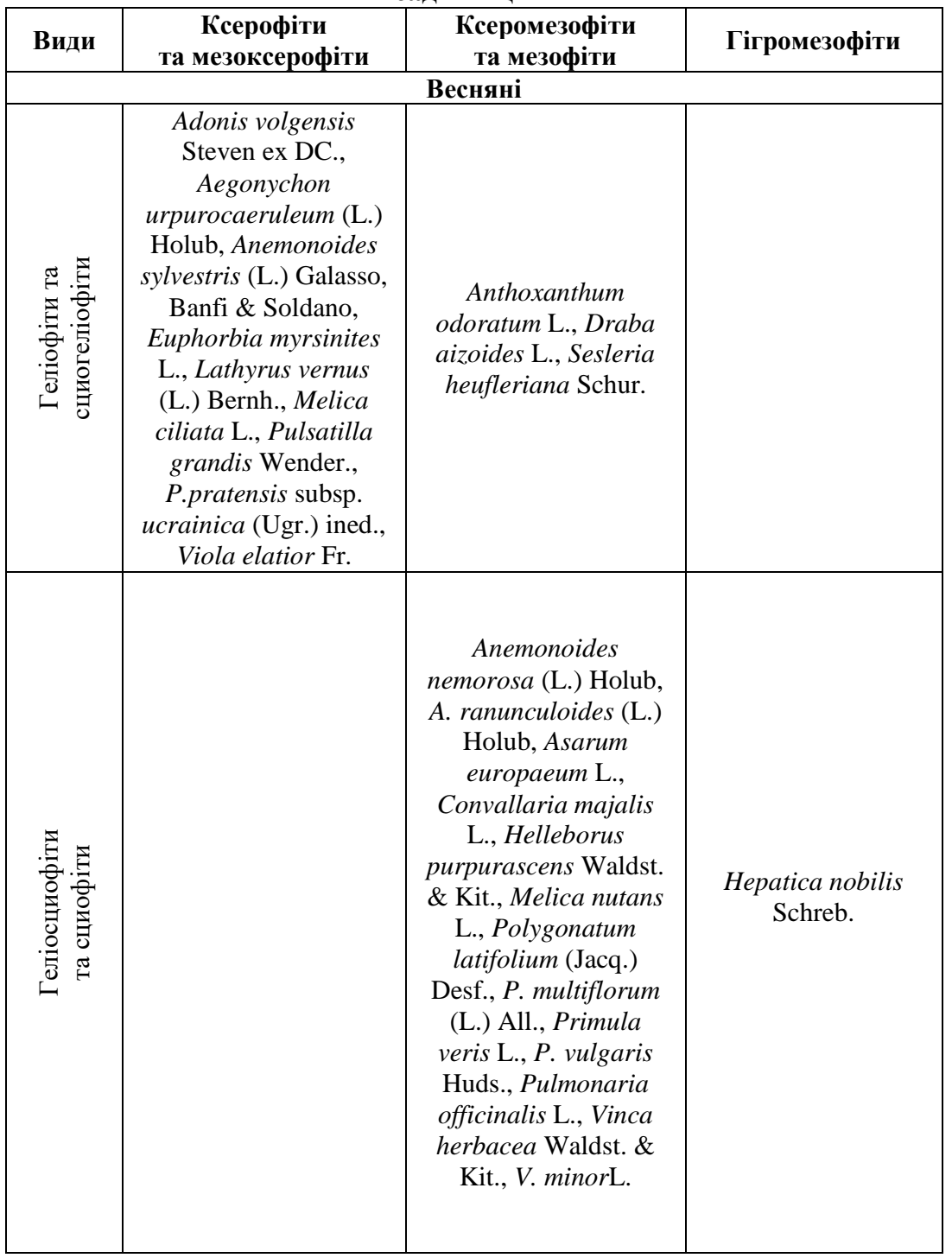


Продовження таблиці

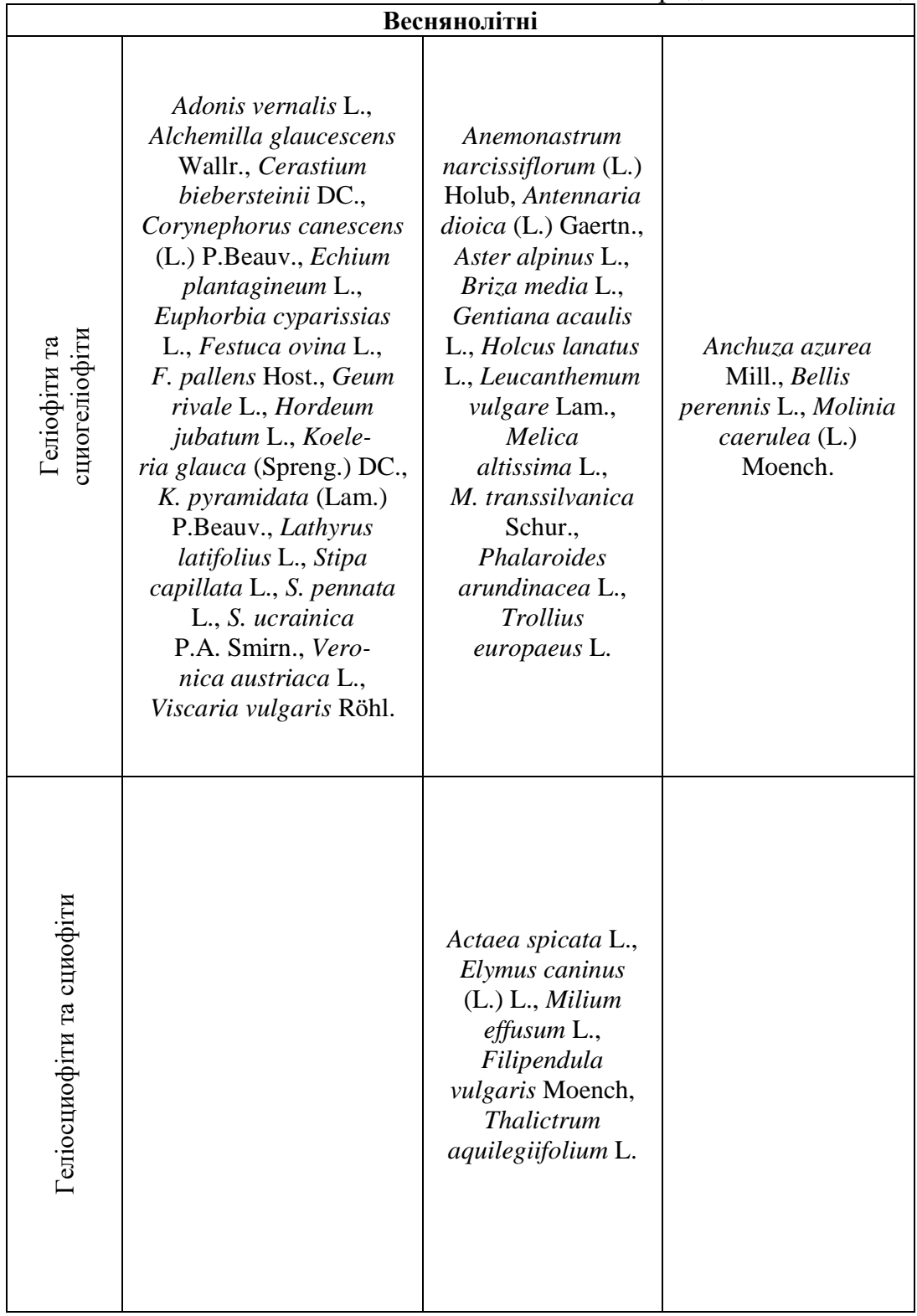


Продовження таблиці

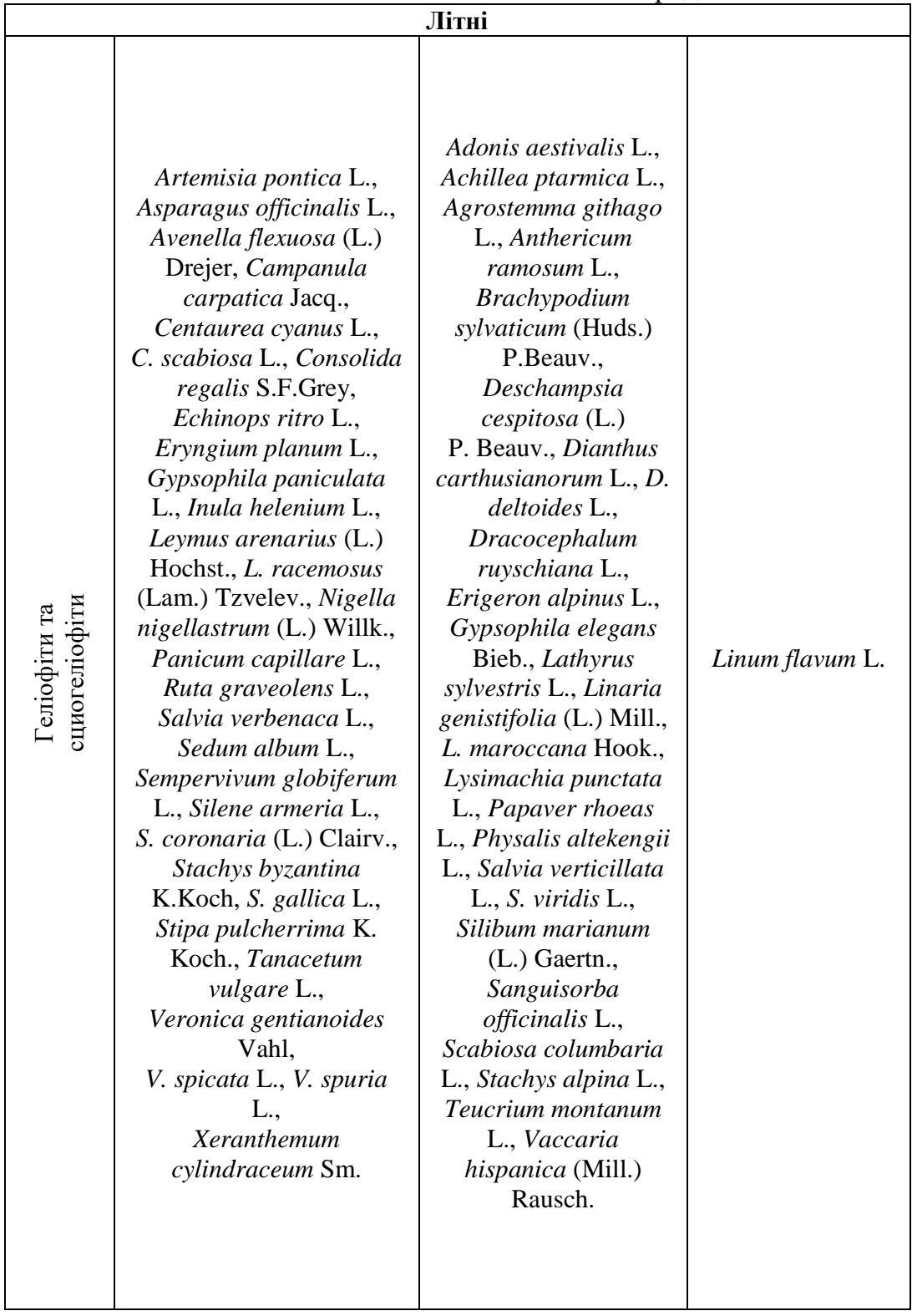


Продовження таблиці

\begin{tabular}{|c|c|c|c|}
\hline 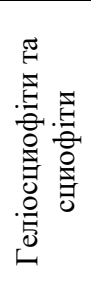 & Geranium sanguineum $\mathrm{L}$. & $\begin{array}{l}\text { Atriplex hortensis } \mathrm{L} ., \\
\text { Campanula glomerata } \\
\text { L., C. latifolia } \mathrm{L} ., C . \\
\text { persicifolia } \mathrm{L} . C . \\
\text { rapunculoides } \mathrm{L} ., C . \\
\text { trachelium } \mathrm{L} ., \\
\text { Geranium bohemicum } \\
\mathrm{L} ., \text { Salvia glutinosa } \mathrm{L} .\end{array}$ & $\begin{array}{l}\text { Filipendula } \\
\text { ulmaria (L.) } \\
\text { Maxim. }\end{array}$ \\
\hline \multicolumn{4}{|c|}{ Літньоосінні } \\
\hline 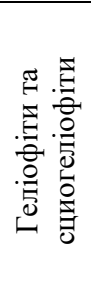 & $\begin{array}{l}\text { Bassia scoparia (L.) A.J. } \\
\text { Scott., Helichrisum } \\
\text { bracteatum (Vent.) } \\
\text { Andrews, Xeranthemum } \\
\text { annum L. }\end{array}$ & $\begin{array}{c}\text { Amaranthus albus } \mathrm{L} ., \\
\text { Calendula arvensis } \\
\text { L., Geranium molle } \\
\text { L., Chrysanthemum } \\
\text { segetum } \mathrm{L} ., \text { Crepis } \\
\text { foetida } \mathrm{L} ., \text { Iberis } \\
\text { pinnata } \mathrm{L} ., \text { Reseda } \\
\text { lutea } \mathrm{L} .\end{array}$ & $\begin{array}{l}\text { Centranthus } \\
\text { ruber (L.) DC }\end{array}$ \\
\hline \multicolumn{4}{|c|}{ Осінні } \\
\hline 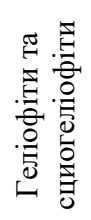 & & $\begin{array}{c}\text { Leucanthemella } \\
\text { serotina }(\text { L.) Tzvelev }\end{array}$ & \\
\hline \multicolumn{4}{|c|}{ Декоративнолистяні } \\
\hline 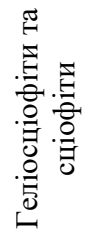 & & & $\begin{array}{l}\text { Asplenium } \\
\text { scolopendrium L., } \\
\text { Dryopteris filix- } \\
\text { mas }(\mathrm{L} .) \text { Schott }\end{array}$ \\
\hline
\end{tabular}

Перспективні для озеленення види представлені різними феноритмотипами та екотипами. Біоекологічні особливості дозволяють впроваджувати досліджувані види у різноманітні типи квітникового оформлення. 
Таким чином, 3 інтродукованих у НБС квітниково-декоративних рослин природної флори України 142 види рекомендовано застосовувати для потреб декоративного садівництва. Диференціація видів за життєвими формами, феноритмотипом та біоморфами дає змогу різнопланового використання рослин в ландшафтних композиціях з різними екологічними умовами. Проведені дослідження показали стійкість інтродуцентів в культурі. Розширення їхніх культурних ареалів сприятиме збереженню біорізноманіття рослин України, зокрема рідкісних та зникаючих.

\section{Література:}

1. Булах П.Е. Теория и методы прогнозирования в интродукции растений. К.: Наук. думка, 2010. 110 с.

2. Карписонова Р.А. Травянистые растения широколиственных лесов СССР. М.: Наука, 1985. 205 с.

3. Матвеев Н.М. Система экоморф растений А.Л. Бельгарда в обновленной интерпретации. Самарская Лука: Бюллетень, 2004. № 14. C. 22-23.

4. Методика фенологических наблюдений в ботанических садах СССР. Москва: Изд-во АН СССР, 1975. 27 с.

5. Червона книга України. Рослинний світ. К.: Глобалконсалтинг, 2009. $900 \mathrm{c}$.

6. Mosyakin S.L., Fedoronchuk M.M. Vascular plants of Ukraine: a nomenclatural checklist. Kiev, 1999. 345 p.

7. The Plant List. URL: http://www.theplantlist.org

8. Plants of The World online. Kew Science. URL: http://www.plantsoftheworldonline.org 